\title{
下肢に神経鞘芽細胞腫 (neurilemmoblastoma)
}

\section{を来たした von Recklinghausen 病の 1 例}

\author{
東宗大学医学部上田内科 \\ 川井倍義, 後藤平

\begin{abstract}
A CASE OF VON RECKLINGHAUSEN'S DISEASE
\end{abstract} \\ ACCOMPANIED BY NEURILEMMOBLASTOMA ON THE RIGHT THIGH \\ Nobuyoshi KawaI and Hitoshi Gotō \\ The Second Department of Internal Medicine \\ Faculty of Medicine, University of Tökyö
}

(Prof. Hideo Ueda)

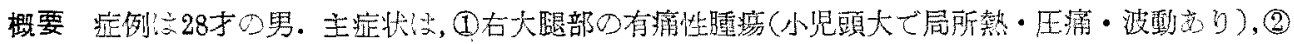

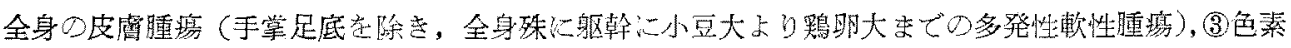

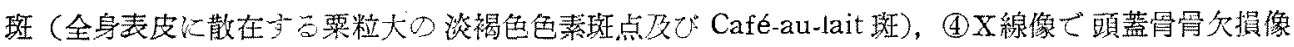

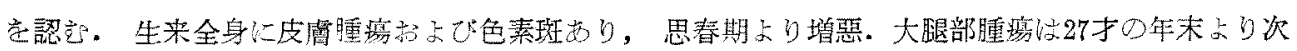

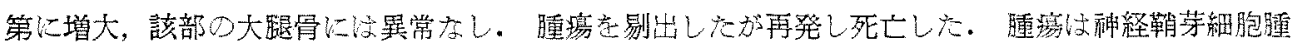

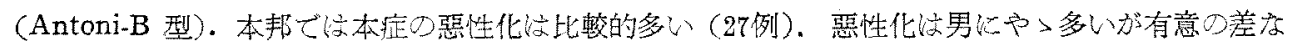
し，ただし年命的に流女の惡性化行男のそれよりる若く起こる。部位的には下肢の深部の种経腫の惡 性化主ることが最も多い，遗伝性执よび惡性化の頻度については報告者により一致しないが，最近 2

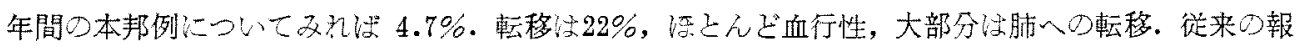

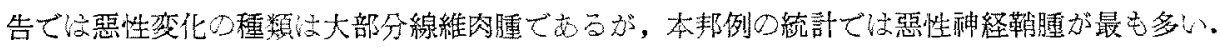

\section{緒㖣}

神経線維腫症，すな⿰ち von Recklinghausen 病（以下R病々略す）注稀有な疾患で泣なく，ま たその惡性化についても従来数多くの症例報告が なされて来た。われわれは，ほとんど全身に多発 した皮䖌腫瘍と斑状色素性母斑, 先天性頭盖骨欠 損等の他に，右大眼㳭部に生じた腫癔が惡性化し て神経鞘芽細胞腫（neurilemmoblastoma）乙な つたR病の1例を経験したので報告し，所せてわ が国における本症の惡性化例について文献的考察 を加えてみたいと思う。

$$
\text { 症例 }
$$

28才, 未婚, 男性. 主訴：1）疼痛ある大䭆

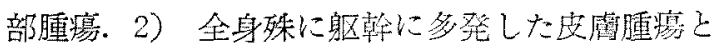

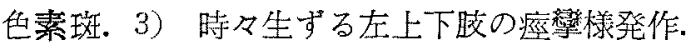
初䛦：昭和 36 年 5 月。家族歴：兄 1 人が右背部 に色素斑を若干有し，また母方の祖母が胃癌で死 亡している。

既往歷：10才の時慢性化膿装中耳资で中耳根 治手街を受计た。11才の時背部を打撗乙疼瘦が続 いた，当时篈椎カリエスを疑われたが，自然に治

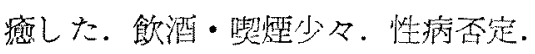

現病歴：生来，全身とくに躯翰に等発した皮

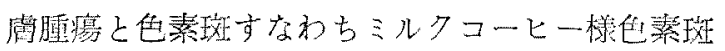
(Caré-au-lait spot)とびまん性細小色索玟点があ

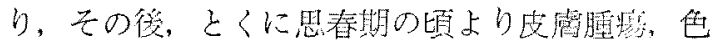
䒺玨とも，その数・大きさを增した。身体，性哭の 
発育は正常であつたが, 知能の発達は不良で, 成績 は常に下位であつた。22才の時, 回盲部痛を訴え, 本症の部分症状と疑われた. 23才の時, 昭和 31 年 1 月の初めより持続的な頭痛と時々起こる軽度の めまいを訴え, 同年 7 月当科に入院. 当時, 皮膚 症状の他に，頭蓋骨X線写畺にて数力所に大きな 骨欠損像と，春㕼造影法で第 4 および第 8 胸椎の 高さに通過障害が認められ，バビンスキー・ロ., ソリモ等の病的反射が両側下肢に陽性に出現, ま た知能指数は26であつた。しかし, 血液像, 屎尿, 血液生化学的検査, 䀒機能, 腎機能, 眴部 X線写 真, 心電是所見, 内分泌機能等には異常を認めな かつた，同年11月退院後，次第に四肢とくに左側 が病性となり，歩行障害も次第に増惡して来た他 に, 時乃痤摰様発作が左上下肢に起こるようにな つた. 27 寸時すなわち昭和 35 年12月右大眼部内側 に腫瘍が生じ，次第に腫大し，36年 3 月末頃から は歩行不能となり，4月末には疼痛増大し, 穿刺 排液するも再び腫大し発熱も続くので，5月19日 当科に再入院した.

入院時現症：体格中等, やせて, 顔貌や>苦 悶状, 体温 $37.4^{\circ} \mathrm{C}$, 前回入院時と比較するとかな りのやせおよび皮膚腫瘍・色素斑の增加が認め

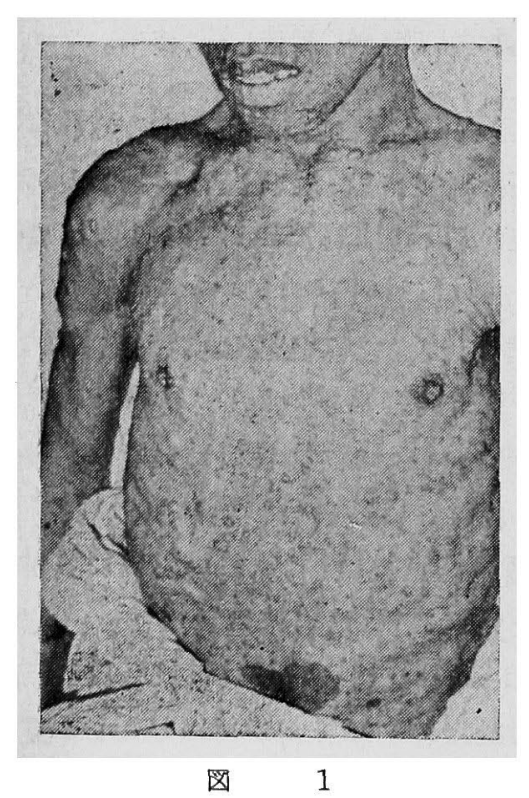

られる，手掌，足底を除き，全身ことに躯幹に小 豆大より䊿鳥卵大までの, 種々の硬度を有する, 平

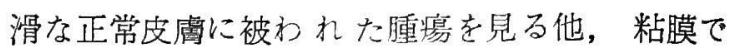

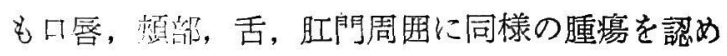
る。また，全身表皮に散在する粟粒大の淡褐色 色素斑点々臍部その他における大小様々なミルク コーヒー様色素玟を認める（図1）. 結節及び色素 斑の部位の知覚は軽度に減弱している. 貧血症, 母斑はない. 胸腹部は理学的に異常なし. 四肢こ とに左上下肢は痤症で, バビンスキー反射をはじ め, 病的反射はすへて陽性. 右大眼内側より外側 にかけて, 小罗頭大の腫瘄あり（図2). 表面の皮 膚は発赤緊張し, 光沢あり. 触診では局所熱・圧 痛・波動あり。該部より末梢の下肢は浮腫高度.

検查所見：血液像は好中球の増加を示し, 頭 部X線写貪では前回々同様, 左偩!頭骨部, 頭頂骨左 側部および後頭骨部に骨欠損像を認わた。トルコ 鞍はや>狭小（図 3 ). 右大腿腫瘍部のX線写貪で は, 腫場部に一致した一様の濃度をもつ陰影がみ られたが, 大腿骨には異常所見なく、針状骨（Spicula）も認められなかつた（因 4). 腫瘍部試験 穿刺液は濃褐色血性の滲出液で, 異型細胞なく, 細菌検査も陰性であつた。 その他, 屎尿, 血液生

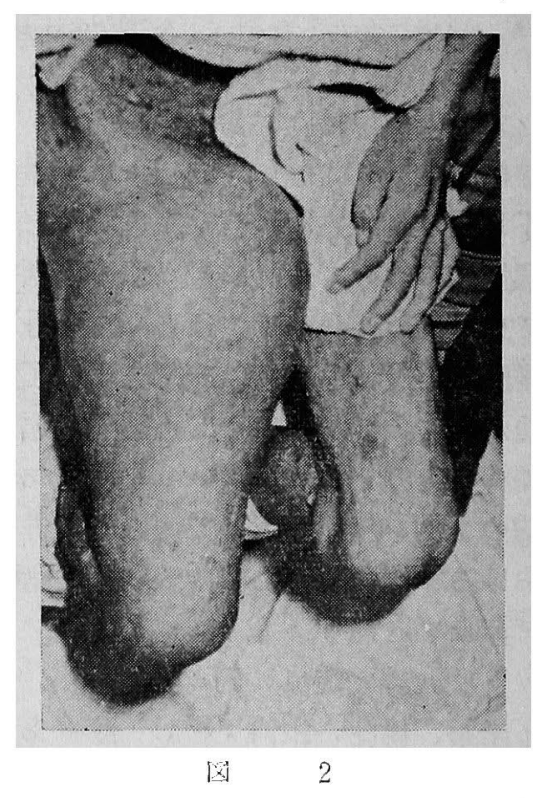




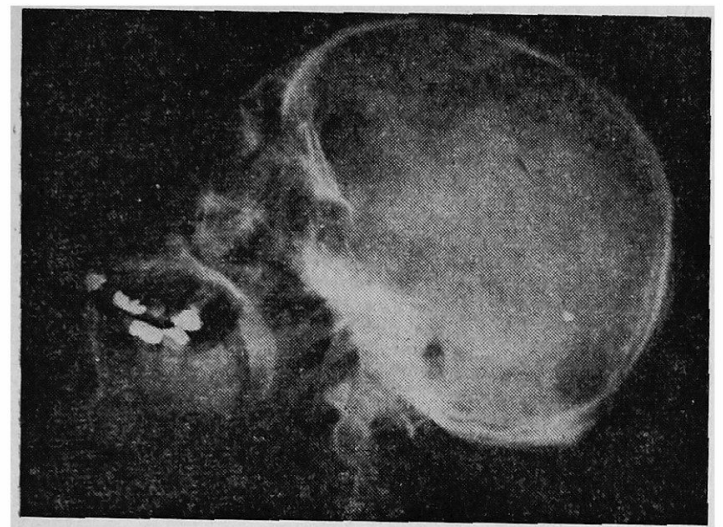

図 3

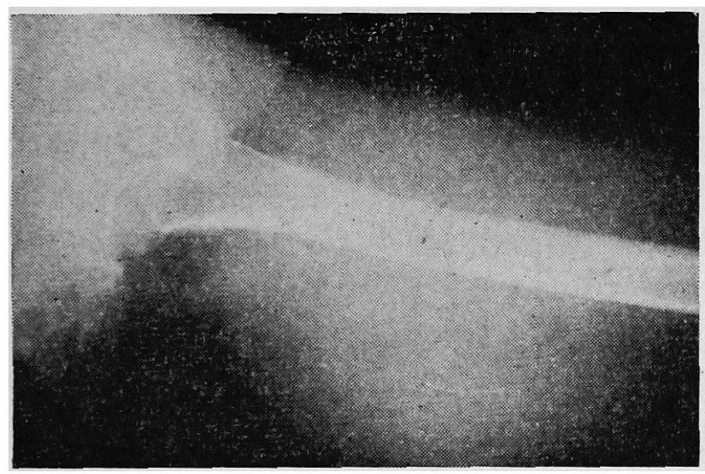

図

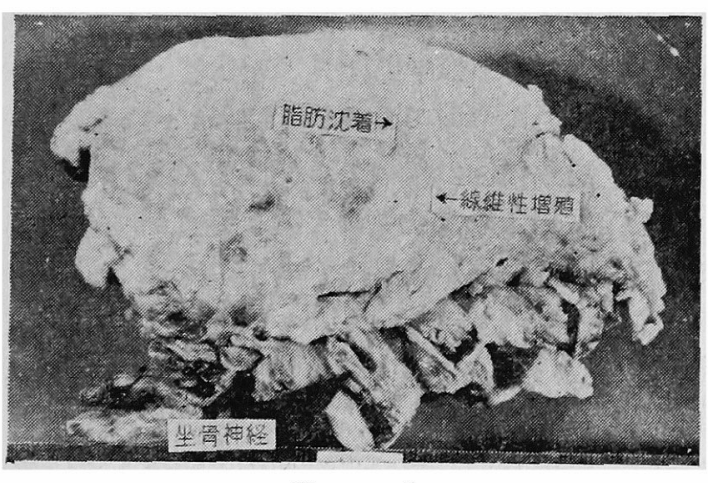

図5

化学的検查扞腎機能, 内分泌㙨能検查, 胸部 X線 写真, 心電図所見等，いずれも正常. 他の皮减腫

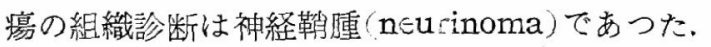

経過：入院後，一般栄養状態が不良であるた め輸液, 抗生物質の投与に努め，6月10日腫瘳剔 除を試みたが腫瘍は再度増大し， 7 月 5 日死亡し

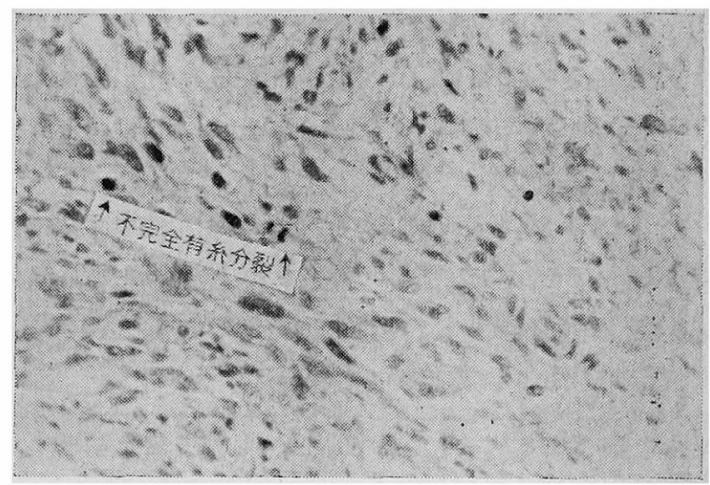

図 6

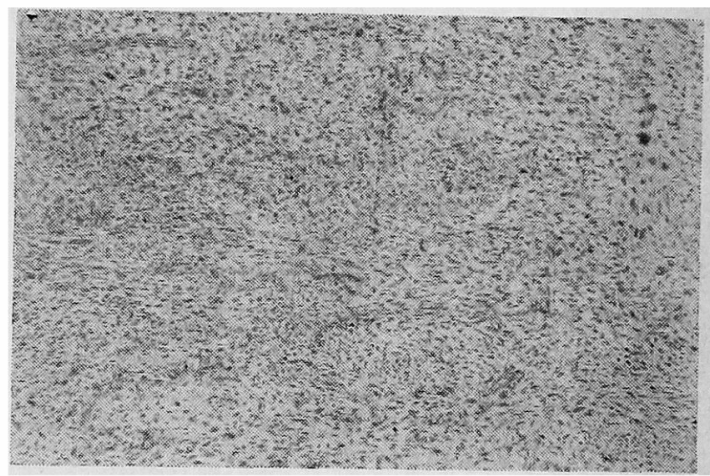

図 $\quad 7$

た。

手術および病理所見：腫瘍は凡そ $15 \times 10 \times 13$ cmで（図5）被膜にお>われ，被膜は坐骨神経と連 続している (図 5 矢印). 被膜の内部は白色軟性組 織および濃赤褐色の液体で充満され，整状を呈 し，血管に富み，容易に出血し，出血総量3000 cc．被膜は周囲との疻着がつよいため，被膜の一 部を残して内容を剔除. 剔出標本は表面粗, 灰 黄色, 彈性軟で, 粘液変性, 小霡胞形成, 脂肪沈 着, 線維性增殖等をみる(図 5 ). 組織学的には, 腫癔細胞は長短紡鍾形，棈円形等を示し，核の 大きさ・形も一定せず，不完全有系分裂（分裂後 期まで〉停止）もかなりみられる（因 6). 紡鍾形 の細胞は, 各所で平行して種々の方向に索状また は渦巻状に走つているが，明膫な観兵式配列は見 られなかつた(図 7 ). 組織の壞死も多く、繊細 な線維が網状になり，組轼内の毛細血管壁の破站 も多くみられ，また表皮基底膜にはメラニンの著 
しい増加がみられた。

病理組擮学的猃断：以上の所兌上り Antoni B 型の神経鞘芽䋚胞腫（neurilemmoblastoma） と診断された。

以上要するに，本症例住全身皮幥に多発する睡

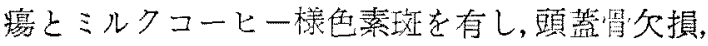
知能低下等を合併したR病で，その他に大跟深部

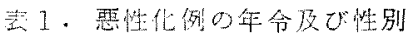

\begin{tabular}{|c|c|c|c|c|c|c|c|}
\hline 捁者 & 年度 & 年 & 柱 & 爱全部位 & 大きさ & 悪性变性 & 転移 \\
\hline 河 村 & 1910 & 32 & $\stackrel{\circ}{\oplus}$ & 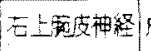 & 成人頭大 & & $?$ \\
\hline 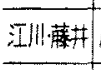 & 1910 & 50 & $\dot{0}$ & 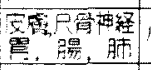 & 惿頍大 & 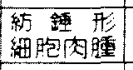 & + \\
\hline 頋 $\boxplus$ & 1931 & $66 !$ & $\delta$ & 皮韵，帕 & $?$ & 線維肉腫 & + \\
\hline 丸田 & 1931 & 52 & $q$ & 上枵面 & $\begin{array}{l}\text { 径 } 21 \mathrm{~cm} \\
13809\end{array}$ & $\begin{array}{l}\text { 紡鍾形 } \\
\text { 細盷腫 }\end{array}$ & $?$ \\
\hline 古森北島 & 1935 & 28 & 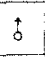 & 後頭部 & 小頭大 & 多 & - \\
\hline 为海 & 1936 & 64 & $\dot{B}$ & 酸頂 却 & 11ンゴ大 & 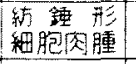 & + \\
\hline 神 沢 & 1936 & 75 & t & 胃 & $?$ & 胃癌症状 & ? \\
\hline 山 $⿴ 囗 十$ & 1939 & $|34|$ & $\hat{b}$ & 後頭部，大腿\} & E 大 & 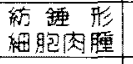 & + \\
\hline 物 野 & 1939 & 30 & 우 & 後腹膜 & ? & 悪性变代 & $?$ \\
\hline 源 & 1941 & 38 & q & 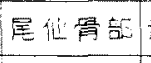 & 起䈐莭大| & 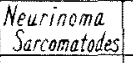 & $?$ \\
\hline 大加菜 & 1942 & 33 & 우 & 二洏盰㸵 & 成人磌大 & 悪性変代 & ? \\
\hline 星野 & 1943 & 25 & 9 & 吕下肢 & 成人䫑大 & 肉腫变性 & ? \\
\hline 諸䕐松浦 & 1949 & 23 & $\stackrel{\circ}{+}$ & 大 腿 & 2 俈 & 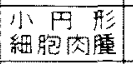 & ? \\
\hline 金野 & 1952 & 34 & q & 網 & $?$ & $\begin{array}{l}\text { Neurinoma } \\
\text { Sercomatodes }\end{array}$ & ? \\
\hline 比奈 & 1952 & $35 \mid$ & ? & 左腋䆚 & $90 \times 70 \times 5,3$ & $\begin{array}{l}\text { Wesurinoma } \\
\text { Sacromatodes }\end{array}$ & $?$ \\
\hline * 沢 & 1952 & 51 & q & 脳底部，項部 & 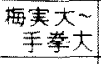 & 肉腫性变化 & ? \\
\hline 村嫩爪 & 1953 & $33 \mid$ & t & 左背部 & $6 \times 6 \times 6 \mathrm{~cm}^{3}$ & $\begin{array}{l}\text { 形 } \\
\text { 細胞肉原 }\end{array}$ & - \\
\hline 藏·森 & 1954 & 51 & $\hat{z}$ & 徭腽謿 & 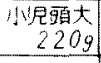 & 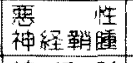 & - \\
\hline tite & 1954 & 64 & $\delta$ & 廎西眼害部 & 成人頍大 & 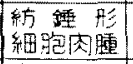 & + \\
\hline 谷野 & 54 & 25 & i & 左上腕部 & 成人頭大 & 变胞胸腫 & $?$ \\
\hline 太田地 & 1955 & 59 & t & 三晹（奇玌) & 手拳大 & $\begin{array}{l}\text { Neurinoma } \\
\text { Sarcomatudes }\end{array}$ & $?$ \\
\hline 足市 & 1956 & 28 & $\hat{\delta}$ & 右幋部 & $\begin{array}{r}\text { 成人䫂大 } \\
6 \mathrm{~kg} \\
\end{array}$ & $\begin{array}{c}\text { Fibromyxo- } \\
\text { sarcoma }\end{array}$ & + \\
\hline 矢 野 & 1959 & 47 & $\delta$ & 吉側琵宜 & 手拳大 & 肉 罣 & $?$ \\
\hline 无田他 & 1959 & 44 & $\hat{o}$ & 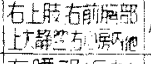 & 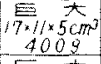 & $\begin{array}{l}\text { Fibrom乃至 } \\
\text { Fibrobliastoma }\end{array}$ & + \\
\hline 高撟地 & 1959 & 28 & to & 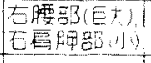 & $5 \pi$ & & - \\
\hline 清水地 & 1959 & 43 & q & 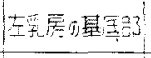 & 小悦大 & 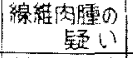 & + \\
\hline |井後㯏 & 1961 & 28 & $\hat{b}$ & 古大腿内赖 & 小湜頍大 & $\begin{array}{l}\text { 神経鞺 } \\
\text { 細胞腄 }\end{array}$ & $?$ \\
\hline
\end{tabular}

表 2

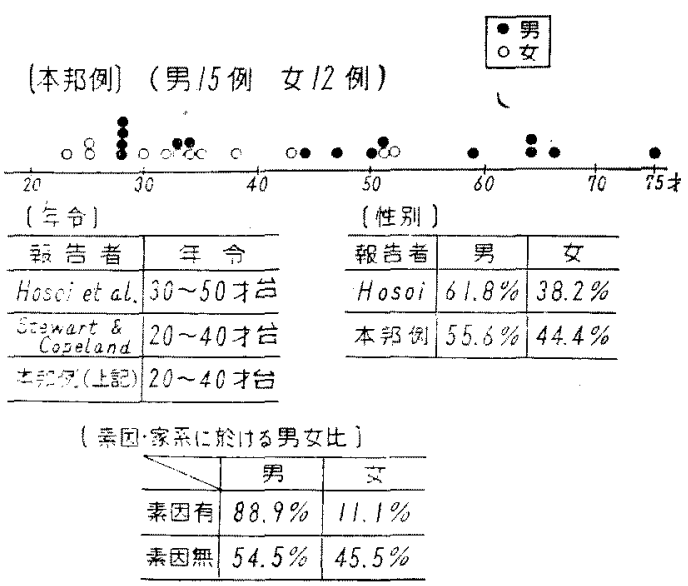

の坐骨神経に連続して生した神経㸃腫が惡性化し て神経鞘芽細胞腫を来たしたものである，遺憾な がら㭧者側の強い要求により剖检不能であったの で，転移の有無および身体の他部分に生じた腫濠 の性格を把握することができなかつた。

\section{考案}

1961年までに本症の悪性化例の報告が約 100 列 あるうち、日本では自験例を含めて27例を算え,惡 性化は比較的多くみられる。彔 1 は惡性化の見ら れた各症例につき，年令・性别・惡性腫瘍の発生 部位・大きさ・組織学的所見・展伝性・その他に ついてまとわたものである。

（1）惡性化例の年令および性別（表2）

表 2 に示す如く，全年令を通じ男女比は15対 12 で有意な差はないが，年令を考慮に入れると両者 の間には明膫な差が現われ，女子例では本症の惡 性化が比較的若年に多いのに比し，男子例のそれ はむしろ中年以後に多い，女子の例が若年に傾く ことは，奸娠ないし内分泌性变動が関保している と想像される[津久井(1955)，太田 (1955)，正木 (1942)]. また惡性化する年悀については，Hosoi （1931）をはじめとする多くの報告者が30〜 50才 台に打発すると述へているが，本邦例のそれはや や若年に傾き，Stewart（1931）および Copeland (1931）のいうょうに20〜40去台に好発してい る. 
（2）惡性化の原因ないし誘因については未だ 確定的な説がなく，機㭜的刺激すなわ方外傷，腫

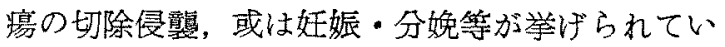
る(太田他1955). Charache(1939)およびHerman （1939）によれば，肉腫性発育をしつ〉あるもの を手術等により剔除するとこれとは関係のな い，他の遠隔部位にあつた腫揚が惡化しうるとい う。もち万ん，かっる機栈的刺激説に反論与る者 もある。

\section{（3）睡場惡性化の好発部位}

Hosoi (1931), Speed (1942), Herman (1939), Preston (1952)，伊藤・森 (1954) 等の症例に著 者らが集めた本邦例を加えた計 103例について発 生部位別に分類すると図8の如くなる（たぐし， 惡性化が 2 力所に起こつたもの 4 例を含み, 腫瘍 数は言十 107). Charache (1939), 伊藤・森 (1954) 等の述へているように，四肢とくに下肢の樑部の 神経腫の惡性化することが最も多い.Thomson は，その半数は坐骨神経加ら出るというが，詳細 に調查した結果を棒グラフにすると図8の如くな り，坐骨神経例は15例で41.7\%を占め, Thomson の成績とぼ゙一致している。その他，後腹膜骨盤 腔，胸部，頭部等にみられる。表度の神経線維腫 が惡化することは非常に稀である。

（4）惡性化例の遺伝性（表2）

$\mathrm{R}$ 病の発生要因として, 遗伝性は古くから重要

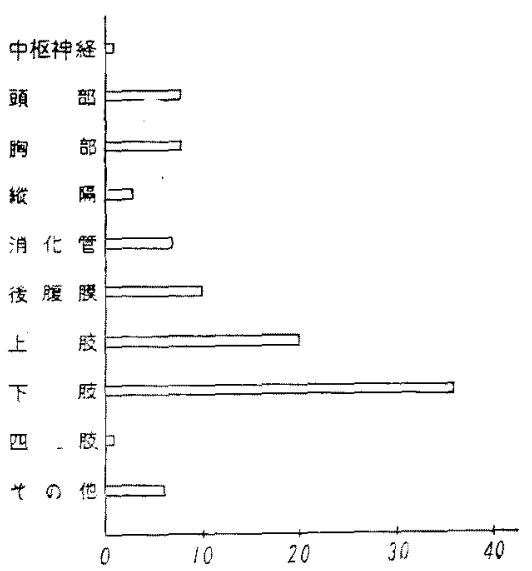

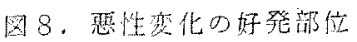

表 3. 㔄性化の頻度

$\begin{array}{ll}\text { Westphalen (1888) } & \text { 数\% } \\ \text { Garré (1892) } & 12 \% \\ \text { Hosoi (1931) } & 13 \% \\ \text { Preston (1952) } & 16 \% \\ \text { Undeutsch (1957) } & 0.01 \% \text { 以下 } \\ \text { 本邦最近2 } 2 \text { 力年間の統計 } 4.7 \%\end{array}$

視されて来ているが，図8の如く報告者により一 定していない，Höckstraによれば，遺伝傾向の 濃厚な R病では，世代が古くなつて初めて惡性変 化を起こすこと代多く，彼の統詰仙よれば，惡性 変化のみられた家系では男29例に対し女10例の割 にR病が存在し，そのうち惡性変化は男14例に対 して女 3 例で，断然男に多い，しかし，遗䛃関䋆 の存しない孤立性の惡性化症例では，思30例に対 して女25例で，ほ心等しく，惡性変化のない家系 でのR病は，男91例に対して女81例でほぶ等しい と報告している。

（5）惡性化例の頻度（表3）

惡性化例の頻度については，0.01\%から16\%ま であり，報告者により一致していない，最近 2 年 間の本邦に扮ける本症についてみると，63例中わ ずか 3 例 $(4.7 \%)$ である。こらの不一致は診 断基準及び症例の集め方の差によるものと考えら 扛る， R 病の惡性化しない症例の中には報告され 好ももあり，軽症例では診断学的にR病として とりあげられ好ものもあり，更に，医師を訪れぬ $\mathrm{R}$ 病の症例名相当の数に上ると考えられるからで ある、従つて，实際は交献で見る率よりも遥かに 少ないものと思われる。

（6）惡性化例 0 予後

本症より発生する惡性化腫癔は被包される傾向 が西り，原発性の惡性腫演に比して浸㵎性発育 をするものが少なく，檕移も比較的末期に起こ

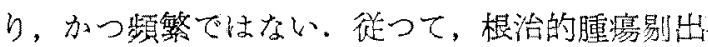
により治瘺させうることもあるというが，それに より他の遠嵒部位にある腫䄈が肉腫性变化を起こ すこともあり，多くは予後不良で再発の頻度は高 く，惡液質・転移・繰返される手術のために死亡 する。而，惡性変化を起こさなくても，身体部位 (例えば中枢神経系)によつては致命的結果をもた 
らすことが多い，転移は Hosoi(1931)によれば， 22\%に起こり，活とんどすべてが血行性で，大部 分肺への転移である。

（7）惡性変化の種類及び R病の本態に対する 考察

従来の報告では Hynie, Cole, Goldshlayをは じめとし，いわゆる線維肉腫が大多数を占めてい るといわれるが，われわれの統計では図17の如 <, 線維肉腫 5 例, 多形細胞肉腫 3 例, 紡鍾型細 胞肉腫 5 例, 惡性神経鞘腫 7 例, 不明 7 例となつ ており，惡性神経䩪腫出最も多い，しかし，一つ のR病からかっる多種類の変化を示す理由は，そ の本態にさか上らねば解明されることはないであ ろう.

R病の本態（所1960）について最古の文献は, Odiér (1803) の「Neuroma 説」である。神経 に多発する腫瘍の存在は Schiffner (1818) 以来 次第に注目されたが，㼛にその当時から本態説が 二説に分かれ，一方は結合織性なりとい（Passavant, Neusinger, 他), 他方は神経性なること を主張した(Heller, Wegener, 他).v. Recklinghausen (1882) は, 多発性の神経腫瘍々皮膚腫 憞との合併が少なくないのを指摘し，両者は共に 詞じ組成の線維腫（fibroma）であつて，その起 源は神経を包む結合織靬，すなわ方神経内膜鞘

(Endoneurium) に求むべきとを述へ，本症 を神経線維腫（症）(neurofibroma, 〜atosis）飞 称した. Verocay (1910) はこれに対し, 次の 如き画期的な説を唱えた。すなち，(1)多発性 神経腫湶の由来壮，結合織 (Endoneurium) に 求むへうでなく，外肧葉性の Schwann 氏䩗細 胞（neurilemmocyte）に求むべきである。すな わちこれは神経性の線維腫愓であり，神経鞺腫 (neurinoma) と命名さるべきである、文，この 組織は一定の相站配列 (palisade formation)

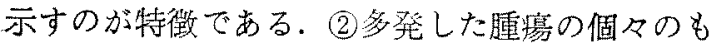
のは必ずしも同棣な形態を示さず，肉眼的及び組 織学的な所見は多くの条件によって左右される. 例えば，核の異型性・獎液滲透・硝子様変性・な
かんずく結合織の量等によつて。(3)本腫燷がしば しば腦の glioma や，腦膜腫癔と合併することか ら推量して, 多発神経腫の発生の基礎に先天的な 広範な神経系の形成異常が仮定される. Herxheimer-Roth(1914)はこれに賛意している．Krumbein, Lauche (1925) は柶状配列に類似の構 造を子宮筋腫などの間葉性線維組織に認めて, Verocayのいう外还葉説に反駁したがこれは類 似による説の立て方のため間もなく覆えされた。 その後の Masson（1932）の唱えた外肧葉性結合 織説 (ectodermal collagen theory), すなわ ち，「末梢神経の神経鞘細胞が結合織を形成する 能力をもつ」という考え方は，ある意味でこれま での動摇に終止符をうつたものといえよう．仮り にこの説を承認するならば，要するに，起源は外 胚葉性であり, 絽成上は外还葉成分と中阫葉性 (Perineurium, Epineurium,その他の結合組織) とから構成されているとみなすことになる。しか し，その本態については，Orzechowski \&認め ているように，今なお橎然としない疑問がモ゙こか に残つている。

四9,10は末梢有䯚神経束の基本構造である. 唯 一の外肧葉性支持組織成分であるところの Sch-

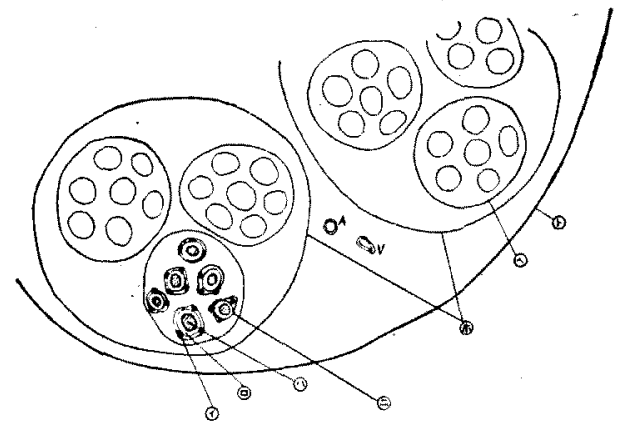
(1) シコワン民靽細胞 (Neurilemmocyte)

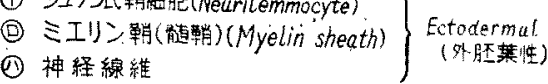

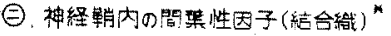
闲、钤経鞘(Peri-neurium)
Q 神経内䁉鞘 (Endo-neurium)
(B) 神経外缕艄 (Epi-neurium) Mesociermal (中显里性) * 共生 (Symbiose)

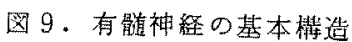




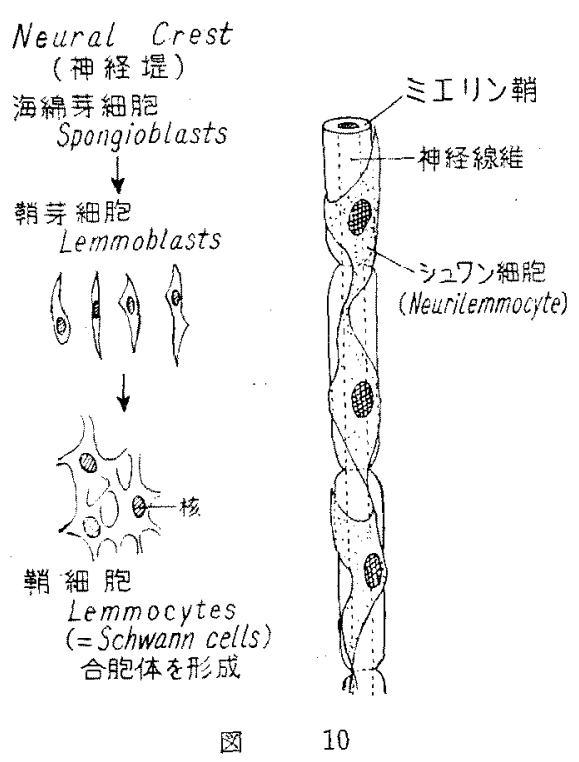

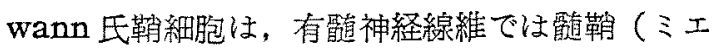
リン鞘）の表面に細網状の合胞体を形成し，及ほ とんど常にその表面に存在する神経内膜鞘（Endoneurium) の間葉性因于，すなわち一般の結合 細胞と共生の状態(Symbiose)にあり，乙かも睡 瘍化に際しても全く同様の過程を踏むため, 睡湯 化した組織の像は全く複雑にみえることから，様 様な愦りが記載されて来たと考えられる。すなわ ち，いわ畃る「神経線維腫」と呼ばれている型 は，図9，10に示す如き末梢神経の全成分の関与が 考えられるが，出来上つた腫癔の型はそれらの諸 要素が, Symbiose (共生) の形で並行的或は様 様な量の混在に上つて成立つために，容易にそれ それれ因子を区別し難い場合が多い，R病はその 代表てある。この場合, 間葉性成分（神経内・周 - 外膜䩓の細胞）の混在が比較的少なくて区別が 容易な場合は，そのま〉Schwannoma (=neurilemmoma) 一惡性化すれぱ malignant Schwannoma (=neurilemmoblastoma 等) 一と呼 ばれる型をとる。「神経鞘腫 (neurinoma)」 とは、これらを広く包含した総括的名称である。

この神経鞘腫は1920年 Antoniにより：つつ型 に分類された。すなわち，特異な Schwann 細胞
核の柵状配列 (regimentation or palisade formation; Palisadenbildung) を示す Antoni A型 之, 粘液腫状 (myxomatous type; myxomatöser Types）を示す不規則な変性型に区別され る、B型ではしばしば小壁胞性の変性（mycrocystic degeneration) の像を示す。この28才の 症例は, 組織所見等よりAntoni-B型に相当するこ とを知つた。この他, 稀に叢状神経腫（plexiform Neuroma）すなわち，袖経幹に沿って念珠状の 腫大を来たす特異な型もみられる。いずれもまれ に惡性化を来たすことが知られている。

\section{総括ならびに結論}

著者らは，28才の男でほとんど全身に多発した 皮盧腫痬と斑状色素性母斑・先天性頭蓋骨欠損等 の他に，右大腿深部に生じた腫瘍が惡性化して神 経䩪芽細胞腫（neurilemmoblastoma）となつた R病の 1例を報告し，垪せて方が国におけるR病 の惡性化例につき交献的考察を行ない, 次の如き 結果を得た。

（1）1961年までに本症の惡性化例が約 100 例 あるうち，本邦では自駼例を含めて27例を算え， 惡性化例は本邦ては此較的多くみられる。

（2）全年令を通じ，惡性化例の男女比には有 意な差はないが，年令別にみると女子の本症の惡 性化は男于のそれよりも若く起こる傾问がある. 男女を通じ，好発年令は20〜40才台である。

（3）惡性変化の原因乃至誘因については未だ 確定的な梳がなく、機械的剌激（外傷・手術等）, 或好妊娠・分娭等が举げられている。

（4）惡性变化は下胶の深部の神経腫において 鼠も多くみられる。その半数近くは坐骨神経から 生ずる.

（5）遺伝性については報告者により一致しな いが，素因有する家系では，世代が古くなるほ ぞ惡性化多く，又，男子の惡性化例が女子のそ れよりも遙加に多い。

（6）惡性化の頻度についても0.01\%から16\% まであり，報告者により一玫していない。れは骖 率基準及び症例の集め方の差によるものと考えら れる，最近 2 年間の本邦における本症についてみ 
ると，63例中わずか 3 例（4.7\%）である。

（7）予後：本症の惡性腫瘍は被包される傾 向があり, 浸㵎性発育をするものが少なく,転移も 少なく（22\%），かつ比較的末期に起こるため，腫 場剔出により全治させうることもあるというが， 多くは予後不良で再発の頻度も高く, 惡液質など により死亡する。

（8）惡性変化の種類： 従来の報告では線維 肉腫が大多数であるが，本邦例の統計では惡性神 経䩗腫が最も多くみられる.

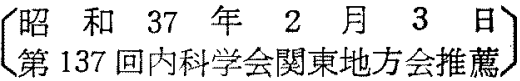

文献

1) 向井紀二：媨 飞神释, 11 (3)：別冊, 1959. 一 2) 神村, 迁見: 臨床皮有泌尿器科, $8: 565,1954$.

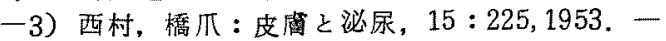
4) 所安夫 : 所安夫眹嗹瘍, $322,1960,-5)$ Stout, A.P.: Atlas of Tumor Path., II (6), 1949. -6) Hosoi, K.: Arch. Surg., 22 : 258, 1931. 7) Charache, Herman: Archiv. Derm, and Syph., XL 135, 1939. - 8) Undeutsch, W.: Dermatologische Wochenschrift $136: 1145,1957$.

-9) Steward: Ann. Surg, 116:81, 1942. 10）足立,他：臨床外科, $13: 384,1958$. 一11）伊 藤, 森：臨床外科, 9:693, 1954. 